\title{
ORGANIZACJA I FINANSOWANIE ŚWIADCZEŃ Z ZAKRESU OPIEKI PALIATYWNEJ I HOSPICYJNEJ W POLSCE DLA OSÓB STARSZYCH - STAN OBECNY I WYZWANIA NA PRZYSZEOŚĆ
}

\section{WPROWADZENIE}

Od wielu lat zjawisko starzenia się społeczeństwa pogłębia się. Zarówno środowiska naukowe, jak również medyczne zwracają uwagę, że systematycznie wydłużająca się średnia długość życia wiąże się z wydłużającym się okresem starości, która w większości przypadków obarczona jest dolegliwościami somatycznymi, jak również pogłębiającymi się deficytami poznawczymi oraz fizycznymi utrudniajaccymi, a wielu przypadkach uniemożliwiajacymi, samodzielne funkcjonowanie. W sytuacji braku wsparcia ze strony rodziny osoby wymagające całodobowej opieki, zgodnie z ustawą z 12 marca 2004 r. o pomocy społecznej $^{1}$, mogą ubiegać się o miejsce w domu pomocy społecznej.

Nieco inaczej przedstawia się sytuacja osób starszych terminalnie chorych (w wielu przypadkach sa to pacjenci onkologiczni w ostatnim stadium choroby), których najbliżsi (z racji braku nie tylko możliwości opieki, ale przede wszystkim niezbędnych umiejętności) zostają zmuszeni do umieszczenia swoich krewnych w instytucjach opieki paliatywnej. Zgodnie z danymi Światowej Organizacji Zdrowia (World Health Organization, WHO), blisko 20 mln osób na świecie (w tym także mieszkańcy Polski) będzie w okresie starości wymagała wsparcia paliatywnego ${ }^{2}$. Powyższe problemy wiążą się także z postępującymi przemianami kulturowymi w społeczeństwie polskim, tj. zmiany modelu rodziny z wielopokoleniowej na jednopokoleniowa (posiadająca jedno dziecko bądź w ogóle nieposiadających dzieci) oraz coraz silniej zauważalną mobilnością młodego pokolenia, prowadzącą do migracji - co skutkuje brakiem możliwości opieki nad starzejacymi się krewnymi.

W związku z prognozami demograficznymi wskazującymi na wzrost liczby zachorowań nowotworowych oraz przedłużająca się, obciążoną chorobami starość wnioskować można, że potrzeba opieki paliatywnej i hospicyjnej (OPiH) będzie stale rosła. Dlatego też niezbędna jest analiza i ocena obowiązujących uregulowań prawno-organizacyjnych oraz możliwości finansowych stosownych podmiotów w zakresie realizacji opieki paliatywnej i hospicyjnej dla osób

\footnotetext{
${ }^{1}$ Ustawa z 12 marca 2004 r. o pomocy społecznej, Dz. U. 2017, poz. 1769 (dalej jako: u.p.s.).

${ }^{2}$ World Health Organization (2014).
} 
starszych. W związku z powyższym celem niniejszego artykułu jest dokonanie tejże analizy oraz zweryfikowanie - na podstawie danych statystycznych i finansowych, których dysponentem jest Narodowy Fundusz Zdrowia (NFZ) oraz Ministerstwo Zdrowia (MZ) - przyjętego założenia o niewystarczającej wysokości i nieskutecznych mechanizmach redystrybucji środków przeznaczanych na opiekę paliatywną i hospicyjna, jak również o przeznaczeniu tych środków wyłącznie na świadczenia, bez uwzględnienia kosztów inwestycyjnych. Tym samym główny problem badawczy analizowany w tekście został sformułowany w postaci następujacego pytania: Jakie są nakłady finansowe i formy organizacji świadczeń z zakresu opieki paliatywnej i hospicyjnej w Polsce? Autorzy dokonując oceny obowiązujących uregulowań prawno-organizacyjnych $\mathrm{OPiH}$ posłużyli się metodą dogmatyczną oraz badaniami nierekatywnymi polegajacymi na analizie danych zastanych, tj. danych statystycznych i finansowych NFZ oraz MZ.

\section{UWARUNKOWANIA PRAWNE I ORGANIZACYJNE OPIEKI PALIATYWNEJ I HOSPICYJNEJ}

\section{Osoba starsza, opieka paliatywna i hospicyjna - operacjonalizacja pojęć}

Zarówno ze społecznego, jak i medycznego punktu widzenia starość stanowi zjawisko wielowymiarowe. Świadczy o tym fakt, że gerontolodzy wyróżniają jej sześć odmian, tj.: chronologiczna, biologiczna, kognitywna, emocjonalna, społeczna oraz funkcjonalna. Mimo że większość zmian związanych ze starzeniem się można usytuować między 60 a 70 rokiem życia, to jednak nie jest to wystarczająca przesłanka dla ustalenia określonej granicy między dojrzałością a starością ${ }^{3}$. Do stanu starości prowadzi proces starzenia się, który można określić jako „naturalny, długotrwały i nieodwracalny proces fizjologiczny, zachodzacy w osobniczym rozwoju żywych organizmów, w tym także człowieka. Ma więc ono charakter zjawiska dynamicznego, przebiegającego w czasie"4. Końcowym etap starzenia się jest starość (za której początek umownie przyjmowany jest 60 lub 65 rok życia).

Zgodnie z definicją ustawowa, jak również terminologia stosowaną przez Światową Organizację Zdrowia za osobę starszą uważa się osobę, która ukończyła 60 rok życia ${ }^{5}$. Jednocześnie, zgodnie z opinią części badaczy, np. Piotra Błędowskiego, możliwe jest także przyjęcie wieku 65 lat jako umownej granicy starości $^{6}$ (na co zwrócono już uwagę wyżej). Z uwagi na podejmowaną w niniejszym artykule tematykę, jak również stosowane w rocznikach demograficz-

\footnotetext{
3 Bois (1996): 14.

4 Pędich(1996): 7.

5 Ustawa z 11 września 2015 r. o osobach starszych, Dz. U. 2015, poz. 1705.

${ }^{6}$ Błędowski et al. (2012): 5.
} 
nych i systemie organizacji usług zdrowotnych podziały na kategorie wiekowe 45-64 lata oraz 65 i więcej lat zdecydowano o przyjęciu definicji osoby starszej jako tej, która ukończyła 65 rok życia.

W związu ze starzeniem się społeczeństwa obserwowany jest dynamiczny wzrost liczby instytucji zajmujących się opieka paliatywną i hospicyjna, np. nowe jednostki $\mathrm{OPiH}$, fundacje wspierające $\mathrm{OPiH}$. W literaturze przedmiotu jeden z punktów odniesienia stanowi opinia WHO w zakresie opieki paliatywnej, która za cel powinna sobie postawić poprawę jakości życia nie tylko osoby terminalnie chorej, lecz także jej najbliższych, w postaci wsparcia w zakresie niwelowania cierpienia fizycznego, psychicznego, społecznego oraz duchowego ${ }^{7}$. Mimo takiego założenia OPiH zwykło się utożsamiać z opieką nad terminalnie chorymi (na ostatnim etapie choroby nowotworowej), w przypadku których nie stosuje się już form aktywnej terapii ${ }^{8}$. Ponadto, zgodnie z § 3.1-2 rozporządzenia Ministra Zdrowia z 29 października 2013 r. w sprawie świadczeń gwarantowanych z zakresu opieki paliatywnej i hospicyjnej ${ }^{9}$, świadczenia OPiH to wszechstronna, całościowa opieka i leczenie objawowe świadczeniobiorców chorujących na nieuleczalne, niepoddające się leczeniu przyczynowemu, postępujące, ograniczające życie choroby. Opieka ta jest ukierunkowana na poprawę jakości życia, ma na celu zapobieganie bólowi i innym objawom somatycznym oraz ich uśmierzanie, łagodzenie cierpień psychicznych, duchowych i socjalnych. Ustawodawca zapewnił świadczenia OPiH osobom obciążonym nieuleczalnymi, postępujacymi, ograniczającymi życie chorobami nowotworowymi i nienowotworowymi (zgodnie z załącznikiem do rozporządzenia). Treść przywołanego aktu prawnego wyraźnie wskazuje, że instytucje kładą nacisk na udzielenie wsparcia w zakresie OPiH przede wszystkim osobom chorym, przy czym zgodnie z $§ 5$ rozporządzenia do zakresu świadczeń gwarantowanych realizowanych w warunkach stacjonarnych zalicza się także opiekę psychologiczną nad świadczeniobiorca $i$ jego rodzina.

Należy zwrócić uwagę, że w zależności od interpretacji i praktycznego zastosowania wskazanego zapisu zmianie może znacząco ulegać wysokość ponoszonych nakładów finansowych w zakresie OPiH. Być może właśnie z uwagi na niewystarczające fundusze odnotowuje się braki w zakresie wsparcia najbliższej rodziny, pełniącej w wielu przypadkach jednocześnie funkcję opiekunów osób terminalnie chorych. Literatura przedmiotu wskazuje natomiast, że potrzeby psychosomatyczne, socjalne i duchowe w stosunku do rodziny osoby terminalnie chorej powinny być zaspokajane także po śmierci pacjenta ${ }^{10}$. Tym samym opieka paliatywna obejmuje pomoc rodzinie nie tylko podczas trwania choroby, ale także w okresie przeżywania żałoby ${ }^{11}$. Ponadto opieka paliatywna powinna być włączana już w momencie, kiedy pojawią się pierwsze symptomy

${ }^{7}$ WHO (2014).

${ }^{8}$ Buss, Lichodziejewska-Niemierko (2008): 277.

${ }^{9}$ Rozporządzenie Ministra Zdrowia z 29 października 2013 r. w sprawie świadczeń gwarantowanych z zakresu opieki paliatywnej i hospicyjnej, Dz. U. 2018, poz. 1185 (dalej jako: rozporządzenie MZ).

${ }^{10}$ Luczak (2007): 1-7.

${ }^{11}$ De Walden-Gałuszko (2004): 17. 
nieuleczalnej choroby (zalecenie Europejskiego Stowarzyszenie Opieki Paliatywnej $^{12}$. Podkreślenia wymaga także znaczaca odrębność OPiH w stosunku do innych form realizowanej opieki medycznej. Ta odrębność wynika przede wszystkim z celów i sposobów sprawowania opieki, charakterystycznej filozofii postępowania względem chorego ${ }^{13}$ (a także jego rodziny), jak również swoistego oswajania tematyki śmierci i cierpienia.

Z powyższego opisu wnioskować można o konieczności specjalistycznego przygotowania osób pracujących w OPiH do wykonywania swojego zawodu. Dlatego też ostatnimi laty (2007-2016) zauważalny jest dynamiczny rozwój w zakresie kształcenia profesjonalnej kadry opiekuńczej ${ }^{14}$, co również nieodłącznie wiąże się ze wzrostem nakładów finansowych. Warto podkreślić, że instytucje realizujące świadczenia z zakresu OPiH często podejmuja samodzielne działania związane $\mathrm{z}$ rozwojem i dokształcaniem swoich kadr oraz wspomagajacych ich wolontariuszy ${ }^{15}$.

\section{Opieka paliatywna i hospicyjna w systemie ochrony zdrowia}

Opieka paliatywna i hospicyjna zajmuje istotne miejsce w systemie ochrony zdrowia, stanowi bowiem holistyczne ujęcie postępowania względem pacjentów i ich rodzin w terminalnej fazie nieodwracalnej choroby, co w związku ze wzrostem zachorowalności na choroby nowotworowe, będzie systematycznie zwiększać krąg osób potrzebujacych. Wskazana forma wsparcia działa na podstawie szeregu aktów prawnych (ustaw, rozporządzeń, zarządzeń) ${ }^{16}$, na potrzeby niniejszego artykułu przywołane zostaną najistotniejsze z nich. Aktem nadrzędnym, wskazującym podstawę finansowania opieki (także OPiH) ze środków publicznych stanowi Konstytucja $\mathrm{RP}^{17}$, zgodnie bowiem $\mathrm{z}$ art. 68 Konstytucji: „każdy obywatel ma prawo do równego dostępu do świadczeń opieki zdrowotnej finansowanych ze środków publicznych, na warunkach i w zakresie określonych w ustawie". Kolejna istotna regulacja w obszarze analiz dotyczących OPiH stanowi art 6. ustawy z 27 sierpnia 2004 r. o świadczeniach opieki zdrowotnej finansowanych ze środków publicznych ${ }^{18}$, wskazujący jednoznacznie, że zadanie władz publicznych polega na zapewnieniu równego dostępu do świadczeń opieki zdrowotnej (w tym również OPIH). Szczegółowe rozwiązania prawne, które określają zakres świadczeń w zakresie analizowanego obszaru zostały ujęte we wspomnianym już rozporządzeniu Ministra Zdrowia z 29 października 2013 r. w sprawie świadczeń gwarantowanych z zakresu opieki paliatywnej i hospicyjnej. W rozporządzeniu precyzyjnie wyszczególnio-

12 Ciałkowska-Rysz, Dzierżanowski (2014): 164.

13 Por. de Walden-Gałuszko (2016): 115.

14 Wesołek (2016): 113.

15 Szerzej Iwański, Sielicka, Jarzębińska (2018): 38-43.

16 Iwański, Sielicka, Jarzębińska (2018): 38-43.

17 Konstytucja Rzeczypospolitej Polskiej z 2 kwietnia 1997 r., Dz. U. 1997, Nr 78, poz. 483 ze zm.

18 Ustawa z 27 sierpnia 2004 r. o świadczeniach opieki zdrowotnej finansowanych ze środków publicznych, Dz. U. 2017, poz. 1938 ze zm. (dalej jako: u.ś.o.z.). 
no wymogi stawiane podmiotom realizujacym usługi oraz zakres świadczeń finansowanych ze środków publicznych we wszystkich formach i rodzajach opieki paliatywnej i hospicyjnej. Kwestie zwiazane $\mathrm{z}$ warunkami zawierania umów na świadczenia z NFZ określone zostały w szeregu zarządzeń ogłoszonych przez Prezesa Narodowego Funduszu Zdrowia ${ }^{19}$. Ponadto, zgodnie z ustawą z 6 listopada 2008 o prawach pacjenta i Rzeczniku Praw Pacjenta ${ }^{20}$, pacjent ma prawo nie tylko do leczenia bólu (art. 20a ust. 1), ale także do umierania w spokoju i godności (art. 20 ust. 2), co również w znacznej mierze dotyka problematyki OPiH.

Pierwszym z warunków, które jest niezbędny do otrzymania świadczeń z zakresu OPiH, jest przedstawienie stosownego zaświadczenia wydanego przez lekarza POZ (podstawowej opieki zdrowotnej) wraz z uzasadnieniem wskazania medycznego (w związku z nierokująca poprawy jednostką chorobowa, o której mowa w załącziku nr 1 do rozporządzenia MZ). Świadczenia, zgodnie z $§ 4$ rozporządzenia MZ mogą być udzielane w warunkach domowych, w hospicjach domowych dla osób dorosłych, ambulatoryjnych (poradnia medycyny paliatywnej), jak również stacjonarnych (hospicjum stacjonarne bądź oddział medycyny paliatywnej).

Świadczenia gwarantowane, realizowane w warunkach stacjonarnych obejmuja m.in.: świadczenia udzielane przez lekarzy, pielęgniarki, leczenie bólu i poszczególnych objawów somatycznych, opiekę psychologiczną rehabilitację, zapobieganie powikłaniom, wykonywanie badań medycznych, opiekę wyręczająca w zakresie przyjmowania pacjentów na oddział medycyny paliatywnej bądź hospicjum stacjonarnego na okres nie dłuższy niż 10 dni (§ 5 rozporządzenia MZ). Z kolei świadczenia gwarantowane, realizowane w warunkach domowych polegają na opiece zdrowotnej udzielanej przez lekarzy i pielęgniarki, leczeniu bólu i innych objawów somatycznych, opiece psychologicznej, rehabilitacji, zapobieganiu powikłaniom, wykonywaniu badań zleconych, ordynacji leków, jak również bezpłatnym wypożyczaniu wyrobów medycznych z hospicjów stacjonarnych (§ 6 rozporządzenia MZ).

W hospicjach domowych dla osób dorosłych, zgodnie z wytycznymi ustawodawcy, zapewnia się m.in.: całodobowy dostęp do świadczeń opieki zdrowotnej (udzielanych przez lekarza i pielęgniarkę), ustalany (zgodnie z potrzebami) dostęp do fizjoterapeuty i psychologa oraz udzielanie wszelkich niezbędnych informacji w zakresie zaleceń pielęgnacyjnych i leczniczych. Natomiast świadczenia realizowane $\mathrm{w}$ ramach opieki ambulatoryjnej obejmuja m.in: porady i konsultacje lekarskie i psychologiczne (w poradni bądź w domu pacjenta), zapewnienie niezbędnych badań diagnostycznych, ordynację leków, oraz zlecanie stosownych zabiegów pielęgnacyjnych (§ 7 rozporządzenia MZ).

${ }^{19}$ W szczególności: zarządzenie nr 73/2013/DSOZ Prezesa Narodowego Funduszu Zdrowia z 9 grudnia 2013 r. w sprawie określenia warunków zawierania i realizacji umów w rodzaju opieka paliatywna i hospicyjna wraz z załącznikami; zarządzenie nr 116/2016/DSOZ Prezesa Narodowego Funduszu Zdrowia z 25 listopada 2016 r. zmieniające zarządzenie w sprawie określenia warunków zawierania i realizacji umów w rodzaju opieka paliatywna i hospicyjna; zarządzenie nr 83/2017/DSOZ Prezesa Narodowego Funduszu Zdrowia z 9 września 2017 r.

${ }^{20}$ Ustawa z 6 listopada 2008 r. o prawach pacjenta i Rzeczniku Praw Pacjenta, Dz. U. 2017, poz. 1317. 


\section{Opieka paliatywna i hospicyjna w instytucjach opieki długoterminowej}

Podkreślenia wymaga fakt, że opieka paliatywna jest realizowana w Polsce w formie domowej bądź stacjonarnej (co szczegółowo opisano wyżej). Krystyna de Walden-Gałuszko zwraca uwagę, że w związku z wyraźnym wyodrębnieniem i odróżnieniem opieki paliatywnej i hospicyjnej od opieki długoterminowej obie formy wsparcia nie mogą być ze sobą utożsamiane. Tym samym zespoły hospicyjne powinny sprawować opiekę nie tylko w domach chorych, ale również względem mieszkańców domów pomocy społecznej (DPS), osób przebywających w zakładach opiekuńczo-leczniczych (ZOL) bądź innych instytucjach opieki długoterminowej ${ }^{21}$. Dla przykładu w domach pomocy społecznej w 2017 r. przebywało około 77 tys. osób ${ }^{22}$, przy czym ponad 12,8\% podopiecznych stanowiły osoby, które ze względu na stan zdrowia nie opuszczają łóżek ${ }^{23}$. Każdego roku w tym typie placówek umiera około 11 tys. osób ${ }^{24}$. Mieszkańcy domów pomocy społecznej wymagający opieki paliatywnej przeważnie uzyskują tego typu świadczenia w placówce, a opiekę nad nimi sprawują członkowie zespołu opiekuńczo-terapeutycznego, wspomagani przez lekarza podstawowej opieki zdrowotnej lub lekarzy specjalistów. Aktualnie obowiązujące przepisy (tj. stan na 16.08.2019) nie przewidują możliwości kontraktowania świadczeń zdrowotnych przez DPS, co powinno zostać bezwzględnie zmienione przez wprowadzenie stosownych regulacji prawnych. Podopieczni takich placówek korzystają ze świadczeń z zakresu opieki paliatywnej i hospicyjnej na takich samych zasadach jak osoby mieszkajace we własnych gospodarstwach domowych. W praktyce w DPS opieka długoterminowa na pewnym etapie życia mieszkańca przyjmuje de facto wymiar opieki paliatywnej i hospicyjnej, co jest niewłaściwe, gdyż - jak już podkreślono - z racji celów i z założenia OPiH różni się zasadniczo od opieki długoterminowej. Tym samym kompetencje, umiejętności i doświadczenie personelu zajmującego się wsparciem długoterminowym nie są tożsame z kompetencjami, umiejętnościami i doświadczeniem pracowników instytucji OPiH.

Warto również zwrócić uwagę na świadczenia realizowane przez wybrane instytucje sektora ochrony zdrowia wyspecjalizowane w opiece długoterminowej, a w szczególności: zakłady pielęgnacyjno-opiekuńcze (ZPO), zakłady opiekuńczo-lecznicze (ZOL), zakłady pielęgnacyjno-opiekuńcze dla pacjentów wentylowanych mechanicznie, przez zespoły długoterminowej opieki domowej dla pacjentów wentylowanych mechanicznie (dorosłych i dzieci), pielęgniarska opiekę długoterminową domową. Pod opieką wymienionych podmiotów bardzo często znajdują się osoby w stanie przedterminalnym i terminalnym choroby.

${ }^{21}$ De Walden Gałuszko (2016): 123.

22 Sprawozdanie MPiPS 03-05 za 2016 (wybrane informacje o ponadgminnych oraz gminnych domach pomocy społecznej, środowiskowych domach samopomocy i placówkach całodobowej opieki - stan na dzień 31.12.2017 r.), <https://www.gov.pl/web/rodzina/statystyka-za-rok-2016> [dostęp: 27.02.2019].

23 Sprawozdanie MPiPS 03-05 za 2016.

24 Sprawozdanie MPiPS 03-05 za 2016. 


\section{FINANSOWANIE ŚWIADCZEŃ OPiH}

Świadczenia z zakresu opieki paliatywnej i hospicyjnej finansowane sa głównie ze środków zebranych w ramach obowiązkowego ubezpieczenia społecznego, których redystrybucję prowadzi Narodowy Fundusz Zdrowia. W przypadku podmiotów ekonomii społecznej (fundacje, stowarzyszenia), które prowadza działalność w omawianym zakresie, znaczną część budżetu stanowią środki uzyskane w ramach odpisów podatkowych dla organizacji pożytku publicznego, zbiórek publicznych oraz wpłat od osób fizycznych i firm ${ }^{25}$.

Tabela 1

Wydatki na świadczenia z zakresu opieki paliatywnej i hospicyjnej w Polsce finansowane ze środków NFZ w latach 2013-2018 (w tys. zł)

\begin{tabular}{|l|r|r|r|r|r|c|}
\cline { 2 - 7 } \multicolumn{1}{c|}{} & $\mathbf{2 0 1 3}$ & $\mathbf{2 0 1 4}$ & $\mathbf{2 0 1 5}$ & $\mathbf{2 0 1 6}$ & $\mathbf{2 0 1 7}$ & $\mathbf{2 0 1 8}$ \\
\hline kraj & 354105 & 382703 & 417437 & 461063 & 678981 & 715035 \\
\hline dolnośląskie & 27106 & 32332 & 35686 & 41365 & 64744 & 68081 \\
\hline kujawsko-pomorskie & 26579 & 26738 & 29155 & 32047 & 47711 & 47060 \\
\hline lubelskie & 15087 & 15279 & 16918 & 18803 & 29947 & 32413 \\
\hline lubuskie & 9506 & 10006 & 11489 & 12624 & 17098 & 15992 \\
\hline lódzkie & 20599 & 22630 & 24242 & 25217 & 36874 & 36871 \\
\hline małopolskie & 31111 & 34178 & 36269 & 40158 & 69984 & 71395 \\
\hline mazowieckie & 39137 & 41110 & 45062 & 49415 & 67425 & 87771 \\
\hline opolskie & 9923 & 11001 & 12092 & 13830 & 19332 & 19884 \\
\hline podkarpackie & 20005 & 23150 & 26537 & 31694 & 47384 & 48497 \\
\hline podlaskie & 10475 & 11280 & 12335 & 13850 & 19000 & 23068 \\
\hline pomorskie & 19687 & 22390 & 23968 & 26316 & 42610 & 44478 \\
\hline śląskie & 46981 & 48663 & 51594 & 56235 & 81905 & 81687 \\
\hline świętokrzyskie & 12408 & 15722 & 17748 & 18988 & 27078 & 30335 \\
\hline warmińsko-mazurskie & 15229 & 15349 & 16187 & 17195 & 23128 & 23580 \\
\hline wielkopolskie & 40505 & 41308 & 45157 & 49412 & 65900 & 65162 \\
\hline zachodniopomorskie & 9767 & 11567 & 12998 & 13914 & 18861 & 18761 \\
\hline
\end{tabular}

Źródło: Plany finansowe NFZ z lat 2013-2018.

W skali kraju wydatki na świadczenia finansowane z budżetu NFZ wzrosły od 2013 do 2018 r. o prawie $102 \%{ }^{26}$. Warto podkreślić, że w tym okresie pomimo odnotowanej niskiej inflacji znacząco wzrosły koszty procedur medycznych, w tym głównie koszty pracy. W każdym województwie odnotowano większe nakłady, lecz zauważalne są duże dysproporcje pomiędzy regionami.

${ }^{25}$ Iwański, Sielicka, Jarzębińska (2018): 93-104.

${ }^{26}$ Wzrost wydatków w zakresie $\mathrm{OPiH}$ wpisuje się w podwojenie wydatków (analiza per capita) na ochronę zdrowia w okresie 2000-2015. Szerzej Sowada et al. (2016): 3. 
W przypadku dolnośląskiego na początku analizowanego okresu kontraktowano świadczenia w kwocie 27106 tys., w 2018 r. osiagnięty został poziom 68081 tys. co stanowi wzrost o 151\%. Zbliżone zwiększenie środków odnotowano w województwie świętokrzyskim (144\%) oraz podkarpackim (142\%). Natomiast najmniej wzrosły w ujęciu 6-letnim nakłady w województwie warmińsko-mazurskim (55\%), wielkopolskim (61\%) i lubuskim (68\%).

W celu dokładnego określania poziomu finansowania świadczeń OPIH przeprowadzona została analiza wydatków w przeliczeniu na mieszkańców w wieku 65 i więcej lat (wykres 1).

\section{Wykres 1}

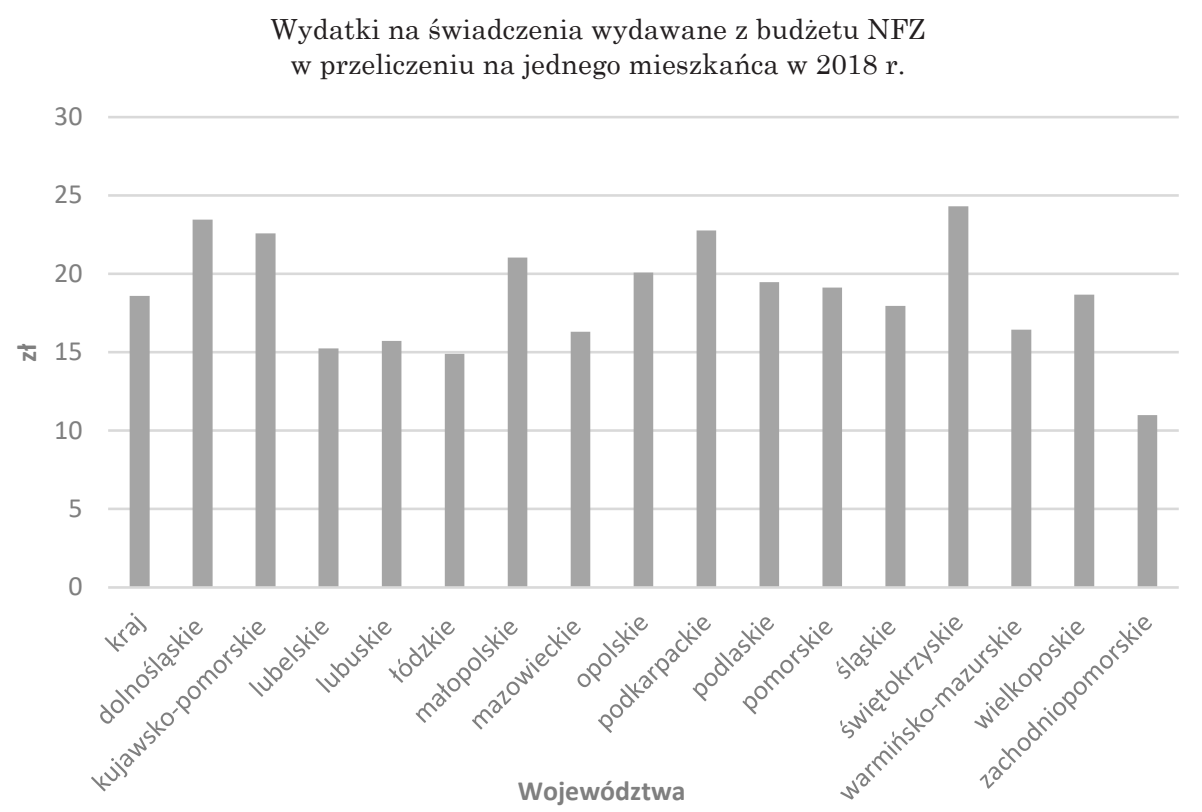

Źródło: Bank Danych Lokalnych 2018; Plan finansowy NFZ na 2018 r. stanowiący załącznik do zarzadzenia nr 51/2018/DEF Prezesa Narodowego Funduszu Zdrowia z 15 czerwca 2018 r. w sprawie uruchomienia rezerwy ogólnej uwzględnionej w planie finansowym Narodowego Funduszu Zdrowia na 2018 r.

W 2018 r. średnio w Polsce na jednego mieszkańca (niezależnie od wieku) wydawano w skali roku 18,06 zł. Największe wydatki odnotowano w województwie świętokrzyskim - 24,31 zł, dolnośląskim - 23,45 zł oraz podkarpackim - 22,77 zł, czyli w tych regionach, w których w okresie 6 lat odnotowano największy procentowy wzrost nakładów w odniesieniu do 2013 r. (tabela 1). $\mathrm{Na}$ drugim biegunie znajdują się województwa: zachodniopomorskie - $11 \mathrm{zł}$, łódzkie - 14,88 zł, lubelskie - 15,24 zł i lubuskie - 15,72 zł.

Na podstawie zebranych danych można stwierdzić, że nakłady ze środków NFZ na świadczenie z zakresu OPIH rosna, lecz w dalszym ciagu zauważalne są duże różnice pomiędzy regionami, które mogą wynikać z polityki prowadzo- 
nej przez poszczególne oddziały NFZ, przy czym również ważny czynnik stoi po stronie świadczeniodawców. W skali kraju wiele placówek prowadzonych jest przez organizacje pozarządowe, co wymaga zaangażowania określonej liczby osób, które - aby uzyskać kontrakt - muszą spełnić stosowne kryteria prawne i warunki w zakresie odpowiedniego zaplecza kadrowego, administracyjno-organizacyjnego oraz sprzętowego. Gdy podmiotem założycielskim jest organ publiczny, możliwe jest pokrycie poczatkowych nakładów ze środków budżetowych (samorządowych lub krajowych). Natomiast część podmiotów z sektora ekonomii społecznej (szczególnie w pierwszej fazie prowadzenia działalności) prowadzi ją jedynie ze środków uzyskanych ze zbiórek 1\% odpisu podatkowego lub wpłat od osób fizycznych i firm. Szczególnie w zakresie prowadzenia działalności w formie hospicjum stacjonarnego konieczne jest poniesienie znacznych nakładów inwestycyjnych, których nie obejmują kontrakty z NFZ. Ubezpieczyciel publiczny finansuje świadczenia, a nie inwestycje.

Analiza budżetów podmiotów OPiH przeprowadzona przez Rafała Iwańskiego, Edytę Sielicką i Anetę Jarzębińską ${ }^{27}$ wykazała, że w przypadku większość placówek kontrakty z NFZ pokrywają od 40\% do 60\% kosztów realizacji świadczeń. Hospicja prowadzone są głównie przez podmioty ekonomii społecznej - fundacje i stowarzyszenia, które uzyskują dodatkowe środki między innymi z odpisu 1\%, darowizn od osób fizycznych i podmiotów prawnych, zbiórek i kwest publicznych. Zakres oferowanych świadczeń przez te podmioty niejednokrotnie znacząco wykracza poza wyszczególnione świadczenia gwarantowane. Podmioty prowadzą wypożyczalnie sprzętu, szkolą wolontariuszy, obejmują wsparciem rodziny chorych, często również po osieroceniu. Niedoszacowanie przez NFZ kosztów realizacji świadczeń ma wymiar systemowy i wymusza na świadczeniodawcach poszukiwanie dodatkowych środków, aby możliwe było prowadzenie pomocowej działalności.

\section{ZAPOTRZEBOWANIE NA ŚWIADCZENIA REALIZOWANE PRZEZ PODMIOTY OPiH}

Dynamiczny rozwój OPiH wynika z wielu czynników, między innymi potrzeb społecznych (w związku ze starzeniem się społeczeństwa), jak również ustawowego obowiązku świadczenia tej formy usług osobom terminalnie chorym $^{28}$. Dostęp do OPiH został potwierdzony stosownymi międzynarodowymi aktami prawnymi (np. konwencja ONZ), stowarzyszenia międzynarodowe zaś traktuja ja jako jedno z praw człowieka ${ }^{29}$. Warto nadmienić, że w $2007 \mathrm{r}$. Polska została sklasyfikowana na 5 miejscu wśród krajów europejskich pod względem rozwoju $\mathrm{OPiH}^{30}$, co wskazuje na wysoką świadomość społeczna i konieczność dostosowywania do zmieniających się warunków społeczno-demograficznych. Jednocześnie zauważa się, że w wyniku realizacji między-

\footnotetext{
27 Szerzej Iwański, Sielicka, Jarzębińska (2018): 38-43.

28 Malarewicz-Jakubów, Jakubów (2014): 358-366.

29 Malarewicz-Jakubów (2017).

30 Centeno et al. (2007): 463-471.
} 
narodowej kampanii „Making a Difference” wprowadzono możliwość objęcia opieką paliatywną osób ze schorzeniami nienowotworowymi, co uznano za najważniejsze osiagnięcie medyczne w opiece nad chorymi. Przy czym w Polsce nadal część chorych na choroby nienowotworowe nie może skorzystać z OPiH, ponieważ ani NFZ, ani MZ nie zakwalifikowały ich jednostek chorobowych (tzn. chorób nienowotworowych) do objęcia $\mathrm{OPiH}^{31}$.

W 2010 r. zwracano uwagę, że w ciagu ostatnich kilkudziesięciu lat zauważono silny wzrost zachorowań na choroby nowotworowe oraz zgonów na skutek tychże chorób, co korelowało ze starzeniem się polskiego społeczeństwa. Jednocześnie podkreślano, iż najsilniejszym czynnikiem ryzyka wystapienia nowotworu jest zaawansowany wiek (dla przykładu w 2008 r. szczyt zachorowań przypadał pomiędzy 50 a 79 rokiem życia) ${ }^{32}$. Już w czasie I Kongresu Demograficznego w 2001 r. Rządowa Rada Ludnościowa zwróciła uwagę na konieczność wprowadzania nowych rozwiązań programowych, w związku z systematycznym wzrostem zachorowalności na nowotwory złośliwe wśród osób w podeszłym wie$\mathrm{ku}^{33}$. Z kolei 65 rok życia w 2016 r. przekroczyło 13\% mężczyzn i 19\% kobiet, dane pochodzące z Krajowego Rejestru Nowotworów wskazuja zaś, że od roku 1980 do 2016 zarówno liczba zachorowań na choroby nowotworowe, jak również zgonów w ich wyniku systematycznie rosła (co, jak już wyżej wskazano, jest bezsprzecznie związane ze starzeniem się społeczeństwa ${ }^{34}$. Z punktu widzenia podejmowanej w niniejszym artykule problematyki (oraz krajowych uregulowań w zakresie kwalifikacji do $\mathrm{OPiH}$ ) wzrost zachorowalność na nowotwory złośliwe w sposób istotny wpływa na zwiększenie zapotrzebowania w zakresie $\mathrm{OPiH}$.

Zgodnie z publikacjami Rządowej Rady Ludnościowej (RRL) odwołującej się do Atlas of Palliative Care in Europe, analizującego dane z 52 krajów (w tym także Polski, która została wysoko oceniona na tle innych krajów europejskich, wspólnie bowiem z Węgrami i Słowenią została uznana za kraj będący w czołówce w aspekcie prowadzenia opieki paliatywnej na terenie Europy Środkowej i Wschodniej). Mimo wszystko wnioski RRL wskazuja, że OPiH nie zaspokaja $\mathrm{w}$ pełni potrzeb ludności, dlatego też niezbędne jest planowanie kolejnych działań, uwzględniajacych przede wszystkim zmieniające się uwarunkowania demograficzne ${ }^{35}$ (wykres 2). Taki stan rzeczy potwierdzaja wyniki zrealizowanej w województwie dolnośląskim kontroli w zakresie funkcjonowania opieki paliatywnej i hospicyjnej, wskazujące na liczne ograniczenia i utrudnienia w dostępie do świadczeń tejże opieki. Wprawdzie Najwyższa Izba Kontroli (NIK) pozytywnie oceniła sprawowanie OPiH nad pacjentami tego województwa, to jednocześnie wykazała nieznajomość rzeczywistych potrzeb w zakresie $\mathrm{OPiH}$, niedostateczną liczbę placówek i zbyt małą liczbę łóżek w na oddziałach medycyny paliatywnej i hospicjach stacjonarnych ${ }^{36}$.

31 Por. Łuczak, Kotlińska-Lemieszek (2011): 3-15.

32 Wojciechowska, Didkowska, Zatoński (2008).

33 Potrykowska et al. (2014): 13.

${ }^{34}$ Wojciechowska et al. (2018): 10-11.

35 Ciałkowska-Rysz, Dzierżanowski (2014): 165.

${ }^{36}$ Funkcjonowanie opieki paliatywnej i hospicyjnej na terenie województwa dolnośląskiego w latach 2012-2014 (I półrocze). Informacja o wynikach kontroli, NIK Delegatura we Wrocławiu. 


\section{Wykres 2}

Ludność w wieku 65 lat i więcej

- lata 1990-2017 (w \%)

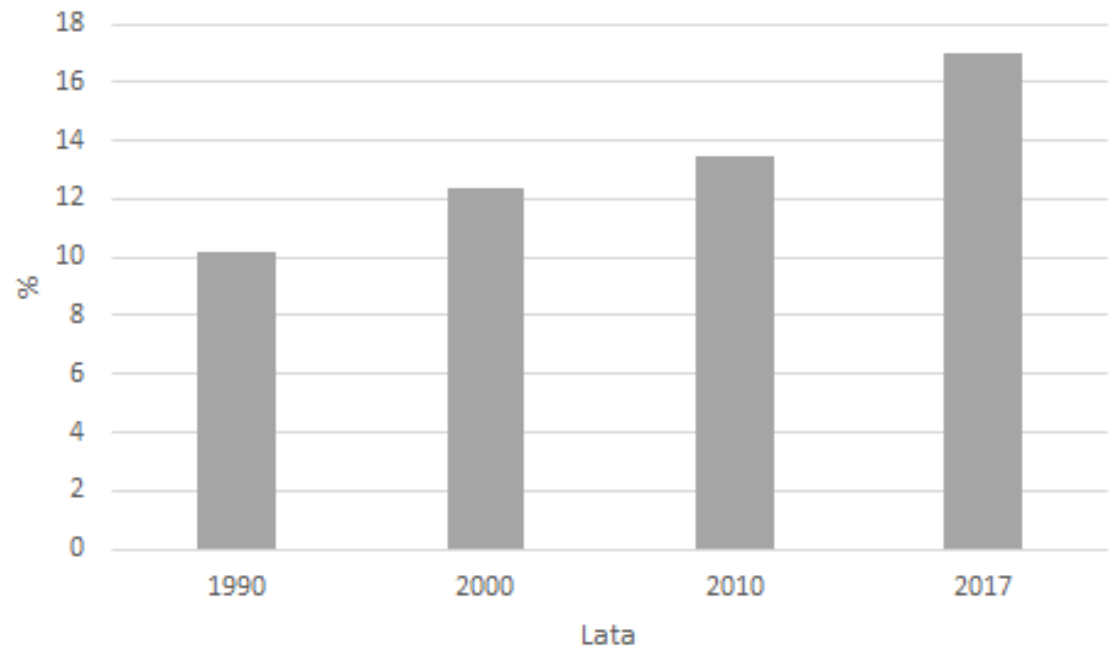

Źródło: Główny Urząd Statystyczny (2018).

Starzenie się populacji przy utrzymujących się silnych trendach w zakresie długoterminowych migracji zewnętrznych ma przełożenie na wzrost zapotrzebowania na usługi świadczone przez podmioty OPiH. W najbliższych latach potencjał opiekuńczy rodzin będzie się zmniejszał, a coraz większa grupa seniorów w ostatnim okresie życia będzie wymagała wsparcia ze strony przedstawicieli sektora ochrony zdrowia. Jeśli nie będzie sprawnego, adekwatnego do potrzeb systemu $\mathrm{OPiH}$, osoby potrzebujące wsparcia w ostatnich dniach życia będą szukały pomocy na oddziałach szpitalnych. Deficyty w zakresie OPiH mają przełożenie na obciążenie innych elementów systemu ochrony zdrowia. Konieczne jest rozszerzenie zakresu chorób uprawniających do świadczeń oraz zmiana mechanizmów finansowania.

\section{WNIOSKI I REKOMENDACJE}

1. Istotne jest, aby postępować zgodnie z zaleceniami wypracowanymi przez Europejskie Stowarzyszenie Opieki Paliatywnej wskazującymi, że opieka paliatywna powinna być włączana już w momencie, kiedy pojawią się pierwsze symptomy nieuleczalnej choroby ${ }^{37}$.

2. Należy doprowadzić do sytuacji, w której zarówno regulacje prawne, wysokość przeznaczonych środków, jak i praktyczna realizacja działań z zakresu

${ }^{37}$ Ciałkowska-Rysz, Dzierżanowski (2014): 164. 
OPiH będą uwzględniały potrzeby osób terminalnie chorych i ich rodzin. Potrzeby psychosomatyczne, socjalne i duchowe osób chorych i ich najbliższych powinny być zaspokajane nie tylko w czasie trwania choroby, ale też w czasie przeżywania żałoby po śmierci beneficjenta świadczeń OPiH.

3. Ważne jest, aby unikać stawiania znaku równości między OPiH a opieka długoterminowa. Obie formy wsparcia skierowane są do innego rodzaju beneficjentów i w żadnym wypadku nie mogą być ze sobą utożsamiane. Mimo że zarówno opiekunowie długoterminowi, jak i opiekunowie zajmujący się opieka paliatywną i hospicyjna wymagają specjalistycznego kształcenia i przygotowania zawodowego, to jednak zakres uzyskiwanej w ramach obu specjalności wiedzy, umiejętności i kompetencji społecznych, jak również charakter wykonywanej pracy są inne.

4. Konieczna jest weryfikacja aktualnie prowadzonej polityki zdrowotnej i ponoszonych w ramach niej kosztów celem systematycznego zwiększania nakładów w tym obszarze. Wprawdzie OPiH jest związana z wysokimi nakładami finansowymi, ale jednocześnie stanowi jedno z praw człowieka, w związku z czym nie powinno się doprowadzać do sytuacji, w których osoby potrzebujące nie mają możliwości skorzystania z takiej formy opieki (co stanowi także art. 68 Konstytucji RP).

5. Istotne jest, by poszerzyć listę schorzeń kwalifikujących do OPiH (także o choroby nienowotworowe).

6. Domy pomocy społecznej powinny mieć możliwość kontraktowania świadczeń z zakresu OPiH, w związku z czym konieczne jest wprowadzenie stosownych regulacji prawnych w tym zakresie.

7. System $\mathrm{OPiH}$ jest systemowo niedofinansowany ze strony głównego ubezpieczyciela (NFZ), deficyty równoważone są dzięki środkom zebranym przez organizacje pozarządowe, które prowadzą placówki.

8. Aktualnie placówki OPiH powstają głównie dzięki inicjatywom podejmowanym przez organizacje pozarządowe, które ponoszą koszty budowy i wyposażenia ze środków uzyskanych ze zbiórek publicznych, odpisów podatkowych i darowizn. Dlatego też sektor publiczny powinien wykazywać większe zaangażowanie w zakresie finansowania budowy i wyposażenia nowych placówek OPiH.

Rafat Iwański

Uniwersytet Szczecinski

rafal.iwanski@usz.edu.pl

https://orcid.org/0000-0001-6345-9677

Anna Szafranek

Państwowa Wyższa Szkoła Informatyki i Przedsiębiorczości w Łomży

aszafranek@pwsip.edu.pl

https://orcid.org/0000-0002-3902-0063

Błędowski, P., Szatur-Jaworska, B., Szweda-Lewandowska, Z., Kubicki, P. (2012). Raport na temat sytuacji osób starszych w Polsce. Warszawa.

Bois, J.-P. (1996). Historia starości. Od Montaigne’a do pierwszych emerytur. Tłum. K. Marczewska. Warszawa. 
Buss, T., Lichodziejewska-Niemierko, M. (2008). Opieka paliatywna w Polsce - od idei do praktyki (również lekarza rodzinnego). Forum Medycyny Rodzinnej 2(4): 277-285.

Centeno, C., Clark, D., Lynch, T. et al. (2007). Facts and indicators on palliative care development in 52 countries of the WHO European region: results of an EAPC Task Force. Palliat. Med. 21(6): 463-471.

Ciałkowska-Rysz, A., Dzierżanowski, T. (2014). Opieka paliatywna w onkologii - aktualne problemy i propozycje rozwiązań systemowych, [w:] A. Potrykowska, Z. Strzelecki, J. Szymborski, J. Witkowski (red.), Zachorowalność i umieralność na nowotwory a sytuacja demograficzna Polski. Warszawa: 164-183.

Główny Urząd Satystyczny (2018). Rocznik Demograficzny. Warszawa.

Iwański, R., Sielicka, E., Jarzębińska, A. (2018). Opieka paliatywna i hospicyjna w ujęciu społecznym i ekonomicznym. Warszawa.

Łuczak, J. (2007). Co to jest leczenie objawowe (paliatywne), opieka paliatywna - hospicyjna i dlaczego warto z nich korzystać? Przegląd Terapeutyczny 3: 1-7.

Łuczak, J., Kotlińska-Lemieszek, A. (2011). Opieka paliatywna/hospicyjna/medycyna paliatywna. Nowiny Lekarskie 80(1): 3-15.

Malarewicz-Jakubów, A. (2017). Wsparcie prawne osób starszych. Warszawa: Lex/el.

Malarewicz-Jakubów, A., Jakubów, P. (2014). Opieka paliatywna w Polsce, [w:] E. Krajewska-Kułak, C.R. Łukaszuk, J. Lewko, W. Kułak (red.), W drodze do brzegu życia. Białystok: 358-366.

Pędich, W. (1996). Ludzie starzy. Warszawa.

Sowada, Ch., Kowalska-Bobko, I., Mokrzycka, A. et. al. (2016). Country Profile - Poland. The activities of older people when healthy aging policy and funding is limited: Institutional and financial dimensions of health promotion for older people. PRO HEALTH 65+ Health Promotion and Prevention of Risk - Action for Seniors. Project Policy Brief 13: 1-9. <http://www. pro-health65plus.eu/userfiles/downloads/policybriefs/PRO-Health\%2065+\%20Policy\%20 brief\%2013a.pdf> [dostęp: 15.08.2019].

Walden-Gałuszko, K. de (2004). Podstawy opieki paliatywnej. Warszawa.

Walden-Gałuszko, K. de (2016). Opieka paliatywna u osób w podeszłym wieku, [w:] M. Cybulski, E. Krajewska-Kułak (red.), Opieka nad osobami starszymi. Przewodnik dla zespołu terapeutycznego. Warszawa: 115-132.

Wesołek, E. (2016). Dostępność opieki paliatywnej i hospicyjnej dla mieszkańców domów pomocy społecznej i placówek opieki długoterminowej - zasadność, możliwości i bariery. Medycyna Paliatywna w Praktyce 10(3): 112-118.

Wojciechowska. U., Czaderny, K., Ciuba, A., Olasek, P., Didkowska, J. (2018). Nowotwory złośliwe w Polsce w 2016 roku. Krajowy Rejestr Nowotworów. Warszawa.

Wojciechowska, U., Didkowska, J., Zatoński, W. (2010). Nowotwory złośliwe ogółem, [w:] Nowotwory złośliwe w Polsce w 2008 roku. Biuletyn Centrum Onkologii: 13-22.

World Health Organization (2014). Global Atlas of Palliative Care at the End of Life. Worldwide Hospice Palliative Care Alliance. London.

Potrykowska, A., Strzelecki, Z., Szymborski, J., Witkowski, J. (red.) (2014). Zachorowalność i umieralność na nowotwory a sytuacja demograficzna Polski. Warszawa.

\section{THE ORGANIZATION AND FINANCING OF PALLIATIVE \\ AND HOSPICE CARE BENEFITS FOR ELDERLY PEOPLE IN POLAND - CURRENT STATE AND CHALLENGES FOR THE FUTURE}

\section{Summary}

The ageing of society and the rise of the tumour incidence among elderly people are the major factors indicating there will be an increased need for palliative and hospice care. Therefore, it is imperative to properly prepare for this increase, in terms of both organization and finance. Since 2013, a state-wide, systematic rise of funds allocated for this particular purpose has been observed, however, it transpires that this is still insufficient. Moreover, there is a problem with access to such support, which can result from the inappropriate and uneven redistribution of the funds allocated for palliative and hospice care. With the aim of exploring this issue, the expen- 
diture on palliative and hospice care benefits in Poland, financed by the National Health Fund (NFZ) in the years 2013-2018, was analysed. This analysis was extended with an investigation of the NFZ's expenditure on the palliative and hospice care benefits per capita, and the percentage of the expenditure on palliative and hospice care in relation to the whole NFZ budget. The article also covers the legal and organizational framework of palliative and hospice care, as well as the financing and the need for such support, and recommendations for the future. In order to answer the following research questions - What is the financial expenditure on hospice and palliative care in Poland? And what is the form of its organization? - the authors analysed the existing data (both statistical and financial) of NFZ and the Polish Ministry of Health.

Keywords: palliative care; hospice care; social policy; elderly people; old age 